\title{
Contribution of the phosphoenolpyruvate:mannose phosphotransferase system to carbon catabolite repression in Lactobacillus pentosus
}

\author{
Stéphane Chaillou, ${ }^{1,2}+$ Pieter W. Postma ${ }^{1}$ and Peter H. Pouwels ${ }^{1,2}$
}

Author for correspondence: Peter H. Pouwels (TNO Voeding). Tel: +31306944 924. Fax: +31306944 466. e-mail: Pouwels@voeding.tno.nl

1 EC Slater Institute, BioCentrum, University of Amsterdam, Plantage Muidergracht 12, 1018 TV Amsterdam The Netherlands

2 TNO Voeding, Department of Applied Microbiology and Gene Technology, PO box 3603700 AJ Zeist, The Netherlands
The role of the Lactobacillus pentosus phosphoenolpyruvate: mannose phosphotransferase system (mannose PTS) in sugar transport and control of sugar utilization was investigated. Growth experiments and measurements of PEP-dependent phosphorylation of sugars, of sugar transport and of catabolic enzyme activity were performed, to compare a wild-type strain with an ElIBMan mutant, LPE6, and a cCPA mutant, LPE4. Fructose uptake in wild-type bacteria demonstrated the presence of two fructose-specific PTSs: a high-affinity system, EII ${ }^{\mathrm{Fru}}\left(K_{\mathrm{m}}=52 \mu \mathrm{M}\right)$ which is inducible by fructose, and a low-affinity system $\left(K_{m}=300 \mu \mathrm{M}\right)$. The latter system was lacking in LPE6 and therefore corresponds to EII ${ }^{\mathrm{Man}}$. LPE6 was unable to phosphorylate glucose, mannose, $\mathrm{N}$ acetylglucosamine and 2-deoxyglucose in a PEP-dependent reaction, indicating that these sugars are substrates of EIIMan. Transport and phosphorylation of these compounds was the same in LPE4 and in wild-type bacteria, although growth of LPE4 on these sugars was impaired. In wild-type bacteria and in LPE4 the activity of EII Fru was lowered by the presence of EIIMan substrates in the growth medium, but this decrease was not observed in LPE6. These results indicate that ElI ${ }^{\mathrm{Man}}$ but not CcPA regulates the synthesis of ElI ${ }^{\mathrm{Fru}}$. Mutations in EII ${ }^{\text {Man }}$ or CcPA resulted in a relief of catabolite repression exerted by EII ${ }^{\text {Man }}$ substrates on the activity of $\beta$-galactosidase and $\beta$-glucosidase, indicating that EII $^{\text {Man }}$ and CCPA are important components in catabolite repression in $L$. pentosus. Fructose-mediated repression of these two enzymes appeared to be correlated with the activity of ElI ${ }^{\mathrm{Fru}}$.

Keywords: mannose PTS, fructose PTS, CcpA, sugar transport, regulation

\section{INTRODUCTION}

Lactobacilli are widely used in the food industry for their ability to rapidly ferment sugars into lactic acid. During catabolism of readily fermentable sugars such as glucose, the synthesis of enzymes involved in the catabolism of other sugars is negatively regulated. This global regulatory phenomenon is commonly termed carbon catabolite repression (CR).

\footnotetext{
† Present address: Institut National de la Recherche Agronomique, Unité Flore Lactique et Environnement Carné, CRJ, Domaine de Vilvert, 78350 Jouy-en-Josas, France.

Abbreviations: 2DG, 2-deoxyglucose; $C R$, catabolite repression; mannose PTS, phosphoenolpyruvate:mannose phosphotransferase system; PEP، phosphoenolpyruvate;
}

It is now well established that in Bacillus subtilis and other low-GC-content Gram-positive bacteria, the dominant CR pathway involves one of the components of the phosphoenolpyruvate (PEP)-dependent phosphotransferase system (PTS), the protein HPr, and a transcription regulator, CcpA (for a review see Stülke \& Hillen, 1999). HPr can be phosphorylated at a Ser-46 residue by an ATP-dependent HPr kinase activated by fructose 1,6-bisphosphate (Deutscher \& Saier, 1983; Galinier et al., 1998; Reizer et al., 1984, 1998). HPr(SerP) was shown to interact with CcpA, resulting in a protein complex which can bind to cis-acting cataboliteresponsive elements (cre) located in the promoter regions of many catabolic operons (Deutscher et al., 1995 ; Fujita et al., 1995; Jones et al., 1997), thereby preventing transcription. The signal for activation of the $\mathrm{HPr}(\mathrm{Ser}-$ 
P)/CcpA pathway is generated during glycolysis, especially when the rate of transport and phosphorylation of the repressing sugars is high.

In B. subtilis the glucose-specific PTS, comprising $\mathrm{HPr}$ and EI and the EII ${ }^{\mathrm{Glc}}$ complex, plays an important role in transport and phosphorylation of glucose (GonzyTréboul et al., 1991). In lactic acid bacteria or sugarfermenting streptococci on the other hand, transport and phosphorylation of glucose is carried out by the mannose PTS (HPr, EI and an EII ${ }^{\mathrm{Man}}$ complex). PTSs have been identified in a number of lactic acid bacteria, e.g. Lactobacillus casei (Veyrat et al., 1994), Lactobacillus sakei (Lauret et al., 1996), Lactobacillus curvatus (Veyrat et al., 1996), Lactococcus lactis (Thompson \& Chassy, 1985), Tetragenococcus halophila (Abe \& Uchiba, 1989) and several species of oral streptococci (for a review see Vadeboncoeur \& Pelletier, 1997). Amongst the species described above, the gene cluster encoding the EII ${ }^{\text {Man }}$ complex of the mannose PTS has been cloned and characterized for L. curvatus (Veyrat et al., 1996) and Streptococcus salivarius (Lortie et al., 2000). The L. curvatus cluster comprises the genes man $A B C D$ encoding the sugar-specific EIIA, EIIB, EIIC and EIID proteins of the EII ${ }^{\text {Man }}$ complex. In S. salivarius, the man gene cluster comprises the gene manL encoding the EIIAB $\mathrm{L}_{\mathrm{L}}^{\mathrm{Man}}$ protein and the genes manMNO encoding respectively EIIC and EIID of the EII ${ }^{\text {Man }}$ complex and a putative regulator of the cluster.

From the major role of the EII ${ }^{\text {Man }}$ complex in glucose transport and phosphorylation in lactic acid bacteria, it may be assumed that the activity of this PTS would affect CR. Indeed, mutations rendering the EII ${ }^{\text {Man }}$ complex inactive resulted in the loss of the preferential use of glucose over several carbon sources such as lactose or ribose in L. casei (Gosalbes et al., 1997; Veyrat et al., 1994) or xylose in T. halophila (Abe \& Uchiba, 1989). It has also been shown that mutations affecting the expression of $S$. salivarius mannose PTS components, especially the $\mathrm{EIIAB}_{\mathrm{L}}^{\mathrm{Man}}$ subunit, have a pleiotropic effect on the synthesis of several metabolic enzymes (Gauthier et al., 1990; Lapointe et al., 1993) as well as on urease activity (Chen et al., 1998) and on an inducible fructose PTS activity (Bourassa \& Vadeboncoeur, 1992). In several instances, a regulatory role in CR has been suggested for the EII ${ }^{\text {Man }}$ complex. However, no information on the relationship between activity of the EII ${ }^{\mathrm{Man}}$ complex and CcpA-dependent CR mediated by glucose is available for $S$. salivarius. Therefore, the mechanisms by which the EII ${ }^{\text {Man }}$ complex is implicated in regulatory functions are not satisfactorily defined.

We have previously demonstrated a role of CcpA in the transcription regulation of the $x y l$ regulon in Lactobacillus pentosus (Chaillou et al., 1998; Lokman et al., 1997). Recently, we have isolated a 2-deoxyglucoseresistant $\left(2 \mathrm{DG}^{\mathrm{R}}\right)$ mutant of L. pentosus, named LPE6, which showed a lack of PEP-dependent phosphorylation of mannose. We showed that mannose PTS activity was restored in LPE6 when plasmid pMJ18, expressing the manB gene encoding the EIIB ${ }^{\text {Man }}$ subunit of the $L$. curvatus EII ${ }^{\text {Man }}$ complex, was introduced (Chaillou et al., 1999). This result indicated that LPE6 presumably contained a mutation in the EIIB $^{\text {Man }}$ domain. In our previous study, we reported the effect of EII ${ }^{\text {Man }}$ mutations on the uptake of xylose, but we did not investigate the possible consequences of these mutations on the utilization of other sugars and on CR. We have now further characterized mutant LPE6 and compared the effect of the EIIB ${ }^{\text {Man }}$ mutation with that of a $c c p A$ deletion. We present in this study results demonstrating that the mannose PTS of L. pentosus regulates expression of the fructose-specific PTS independently of CcpA.

\section{METHODS}

Bacterial strains and plasmids. The following L. pentosus strains were used: MD353 (wild-type; Lokman et al., 1991), LPE4 ( $\triangle c c p A$ mutant, $\mathrm{Ap}^{\mathrm{R}} \mathrm{Em}^{\mathrm{R}}$; Lokman et al., 1997), LPE6 $\left(2 \mathrm{DG}^{\mathrm{R}}\right.$ mutant; Chaillou et al., 1999). The following plasmid was used: pMJ18 (containing the manB gene from L. curvatus; $\mathrm{Ap}^{\mathrm{R}} \mathrm{Em}^{\mathrm{R}}$; Veyrat et al., 1996).

Growth conditions. During all the experiments described in this study, cells were cultivated on the Lactobacillus synthetic rich MCD medium (Lauret et al., 1996), supplemented with $50 \mathrm{mg} \mathrm{l}^{-1}$ each of L-aspartic and L-glutamic acid, which are essential amino acids for species related to Lactobacillus plantarum (Ledesma et al., 1977). All carbohydrates were added at a final concentration of $0.5 \%(\mathrm{w} / \mathrm{v})$ and erythromycin $\left(5 \mu \mathrm{g} \mathrm{ml}^{-1}\right)$ was added when necessary. All incubations were carried out at $37^{\circ} \mathrm{C}$ in non-shaken tubes containing either $25 \mathrm{ml}$ (growth, phosphorylation and uptake studies) or $5 \mathrm{ml}$ (enzyme assays) of MCD medium. Inoculations were performed by diluting an MCD culture $\left(\mathrm{OD}_{600} 1 \cdot 0\right.$; obtained after 8-24 h incubation depending on the energy source used) $1 / 100$ into fresh medium.

Preparation of permeabilized cells. Bacterial cultures were cultivated as described above, washed twice with ice-cold $50 \mathrm{mM}$ potassium phosphate buffer ( $\mathrm{pH} 6.5)$ containing $2 \mathrm{mM}$ $\mathrm{MgSO}_{4}$ (KPM buffer), resuspended in 1/100 of culture volume in KPM containing $20 \%(\mathrm{w} / \mathrm{v})$ glycerol, and rapidly frozen in liquid nitrogen and kept at $-80^{\circ} \mathrm{C}$ until use. After thawing, cells were washed once with KPM buffer and then resuspended to a final $\mathrm{OD}_{600}$ of 50 in $50 \mathrm{mM}$ potassium phosphate buffer (pH 6.5) containing $12.5 \mathrm{mM} \mathrm{NaF}, 5 \mathrm{mM} \mathrm{MgCl}$ and $2.5 \mathrm{mM}$ dithiothreitol. Cells were permeabilized as follows. First, $2 \cdot 5 \mu \mathrm{l}$ toluene/acetone $(1: 9, \mathrm{v} / \mathrm{v})$ was added per $250 \mu \mathrm{l}$ cell suspension and the mixture was vortexed for 5 min at $4{ }^{\circ} \mathrm{C}$. Cells were then rapidly centrifuged $\left(150 \mathrm{~g}\right.$, at $4{ }^{\circ} \mathrm{C}$ for $\left.2 \mathrm{~min}\right)$ and the supernatant was discarded. This step was necessary to remove the high cytoplasmic PEP pool of L.pentosus. The cell pellet was resuspended again in the same buffer $\left(\mathrm{OD}_{600} 50\right)$ and treated once more with toluene/acetone as described above. After 5 min of vortexing, permeabilized cells were kept on ice.

PEP- and ATP-dependent ${ }^{14} \mathrm{C}$-labelled carbohydrate phosphorylation assay. For each assay, $2 \cdot 5 \mu \mathrm{l}, 5 \mu \mathrm{l}$ and $10 \mu \mathrm{l}$ of permeabilized cells $\left(\mathrm{OD}_{600} 50\right)$ were incubated in a final volume of $100 \mu \mathrm{l} 50 \mathrm{mM}$ potassium phosphate buffer (pH 6.5) containing $12.5 \mathrm{mM} \mathrm{NaF}, 5 \mathrm{mM} \mathrm{MgCl}, 2.5 \mathrm{mM}$ dithiothreitol, $10 \mathrm{mM}$ PEP or ATP, and $10 \mathrm{mM}{ }^{14} \mathrm{C}$-labelled carbohydrate (specific activity 200 d.p.m. nmol ${ }^{-1}$ ). After incubating for $15-30 \mathrm{~min}$ at $37^{\circ} \mathrm{C}$, the phosphorylated carbohydrates were separated on Dowex AG 1-X2 columns as 
described previously (Postma, 1977), and the radioactivity was determined by liquid scintillation counting.

Uptake of D-[U- $\left.{ }^{14} \mathrm{C}\right]$ fructose in starved cells. Cells for uptake studies were cultivated, harvested, washed and frozen as described above for the preparation of permeabilized cells. For transport measurements, cells were first washed once with $\mathrm{KPM}$ buffer and resuspended at a concentration of $0.5 \mathrm{mg}$ dry wt $\mathrm{ml}^{-1}$ in $100 \mu \mathrm{KPM}$ buffer. This cell suspension was incubated for $2 \mathrm{~min}$ at $37^{\circ} \mathrm{C}$ and transport was initiated by addition of $\mathrm{D}-\left[\mathrm{U}-{ }^{14} \mathrm{C}\right]$ fructose at the concentrations indicated (specific activity ranged from 330 d.p.m. nmol ${ }^{-1}$ to 38000 d.p.m. mmol $^{-1}$ ). After $15 \mathrm{~s}$ of uptake, $2 \mathrm{ml}$ ice-cold $0 \cdot 1 \mathrm{M} \mathrm{LiCl}$ was added to the cells and the samples were rapidly filtered through glass-fibre filters (Whatman GF/F) and washed with an equal amount of ice-cold $0 \cdot 1 \mathrm{M} \mathrm{LiCl}$. The radioactivity was determined by liquid scintillation counting.

Enzyme assays. $\beta$-Glucosidase and $\beta$-galactosidase activities were determined at $37^{\circ} \mathrm{C}$ in $750 \mu \mathrm{l} \mathrm{KPM}$ buffer containing 10-20 $\mu \mathrm{l}$ permeabilized cells $\left(\mathrm{OD}_{600}, 50\right)$ and $5 \mathrm{mM} p$ nitrophenyl $\beta$-D-glucopyranoside or $o$-nitrophenyl $\beta$-Dgalactopyranoside, respectively. Adding $250 \mu \mathrm{l} 1 \mathrm{M} \mathrm{Na}_{2} \mathrm{CO}_{3}$ stopped the reaction and the $A_{410}$ was measured. The activity is expressed as nmol $p$-nitrophenol formed $\mathrm{min}^{-1}$ (mg dry wt $)^{-1}$.

Radiochemicals. D-[U- $\left.{ }^{14} \mathrm{C}\right]$ Glucose $\left(11.5 \mathrm{GBq} \mathrm{mmol}^{-1}\right)$, D-[U$\left.{ }^{14} \mathrm{C}\right]$ mannose $\quad\left(10 \cdot 6 \mathrm{GBq} \quad \mathrm{mmol}^{-1}\right), \quad \mathrm{D}$-[U- $\left.{ }^{14} \mathrm{C}\right]$ fructose $\left(11 \cdot 9 \mathrm{GBq} \mathrm{mmol}^{-1}\right), \quad$ 2-deoxy-D-[U- $\left.{ }^{14} \mathrm{C}\right]$ glucose $\quad(11 \cdot 1 \mathrm{GBq}$ $\left.\mathrm{mmol}^{-1}\right)$, and $\mathrm{N}$-acetyl-D- $\left[1-{ }^{14} \mathrm{C}\right]$ glucosamine $(2 \cdot 11 \mathrm{GBq}$ $\mathrm{mmol}^{-1}$ ) were obtained from Amersham.

\section{RESULTS}

\section{Growth characteristics of LPE6 and LPE4}

To unravel the effects of EIIB ${ }^{\text {Man }}$ and $c c p A$ mutations on sugar utilization, we studied the growth of wild-type bacteria and of mutants LPE6 (EIIB ${ }^{\text {Man }}$ mutant) and LPE4 $(\Delta c c p A)$ on various sugars that are fermented by $L$. pentosus (Table 1 ). Mutant LPE6 had doubling times on glucose, mannose and $\mathrm{N}$-acetylglucosamine which were approximately two to three times longer than those determined for the wild-type strain MD353, whereas LPE6 and MD353 exhibited the same doubling time on sucrose. Strain LPE6/pMJ18, carrying manB from $L$. curvatus on a multi-copy plasmid grew faster on glucose, mannose and $\mathrm{N}$-acetylglucosamine than the strain without plasmid, although the doubling times remained $\sim 20 \%$ higher than those of the parental strain, MD353. These results suggested that EII ${ }^{\mathrm{Man}}$ is the common transporter for glucose, mannose and $\mathrm{N}$-acetylglucosamine. It should be noted, however, that mutant LPE6 was still able to grow, albeit slowly, on the three energy sources. Interestingly, LPE6 grew $1 \cdot 5$-fold faster on fructose than MD353. Furthermore, LPE6/pMJ18 grew about $2 \cdot 6$-fold more slowly on fructose than the untransformed mutant, and 1.7-fold more slowly than wild-type bacteria. This last observation suggested a link between the mannose PTS and the utilization of fructose. Finally, we found that the phenotype of mutant LPE4 $(\triangle c c p A)$ was different from that of LPE6. Mutant LPE4 grew at least 1.3- to $1 \cdot 7$-fold more slowly than the wild-type strain on the various energy sources tested. Further growth analysis of mutants LPE4 and LPE6 with other sugars (e.g. maltose, ribose, arabinose) revealed that mutant LPE4 invariably grew 1.3- to 2 -fold more slowly than MD353 whereas no difference could be observed with mutant LPE6 (data not shown). Therefore, in contrast to what was observed with LPE6, growth impairment of LPE4 is independent of the energy source used.

\section{Rates of sugar phosphorylation in wild-type L. pentosus, and mutants LPE4 and LPE6}

In order to understand the growth behaviour of the strains described above, the rates of phosphorylation of several sugars were determined in permeabilized, exponentially growing cells (Table 2). PEP- and ATPdependent phosphorylation could be detected for glucose, mannose, $\mathrm{N}$-acetylglucosamine and fructose, although the rates of ATP-dependent phosphorylation were very low for fructose. Mutant LPE6 had lost most of the PEP-dependent phosphorylation of glucose, mannose and $\mathrm{N}$-acetylglucosamine, but in LPE6/pMJ18 this activity was restored to $70-100 \%$ of that in MD353. These results confirmed the role of EII ${ }^{\text {Man }}$ as the main transport system for these sugars as well as for 2DG [we found that 2DG could also be phosphorylated in a PEP-dependent reaction in wild-type bacteria at a rate of $51 \pm 4 \mathrm{nmol} \mathrm{min}{ }^{-1}(\mathrm{mg} \mathrm{dry} \mathrm{wt})^{-1}$, and this phosphorylation rate was reduced to about $0.5 \mathrm{nmol} \mathrm{m^{-1 }}$ (mg dry wt $)^{-1}$ in LPE6]. In contrast,

Table 1. Doubling times of several $L$. pentosus strains in MCD medium supplemented with $0.5 \%(\mathrm{w} / \mathrm{v})$ of different energy sources

The doubling time values are the means of three separate experiments and their standard deviations never exceeded $15 \%$ of the mean. Nag, $\mathrm{N}$-acetylglucosamine.

\begin{tabular}{|llccccc|}
\hline \multirow{2}{*}{ Strain } & \multirow{2}{*}{ Plasmid } & \multicolumn{5}{c|}{ Doubling time (min) on: } \\
\cline { 3 - 6 } & & Glucose & Mannose & Nag & Fructose & Sucrose \\
& & 97 & 104 & 96 & 135 & 95 \\
MD353 & - & 278 & 230 & 250 & 90 & 96 \\
LPE6 & - & 118 & 127 & 118 & 228 & 92 \\
LPE6 & pMJ18 & 149 & 151 & 163 & 169 & 156 \\
LPE4 & - & &
\end{tabular}


Table 2. Rates of PEP- or ATP-dependent phosphorylation of various sugars measured in permeabilized cells of $L$. pentosus

Growth was performed in MCD medium at $37^{\circ} \mathrm{C}$ and measurements were carried out in permeabilized exponentially grown cells $\left(\mathrm{OD}_{600} \sim 0 \cdot 5\right)$. All strains were pre-grown for $8 \mathrm{~h}$ in $\mathrm{MCD}$ medium containing $0.5 \%(\mathrm{w} / \mathrm{v})$ of glucose $(\mathrm{Glc})$, mannose (Man), $N$-acetylglucosamine $(\mathrm{Nag})$ or fructose (Fru) according to the phosphorylation tested. Experiments were carried out with $10 \mathrm{mM}$ PEP or ATP, and $10 \mathrm{mM}{ }^{14} \mathrm{C}$-labelled sugar (specific activity $0 \cdot 1 \mu \mathrm{Ci} \mathrm{nmol}{ }^{-1}$ ), under conditions described in Methods. Phosphorylation rates are expressed as nmol ${ }^{14} \mathrm{C}$-labelled sugar

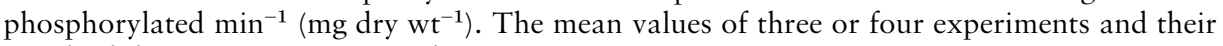
standard deviations are presented.

\begin{tabular}{|c|c|c|c|c|c|c|c|c|c|}
\hline \multirow[t]{2}{*}{ Strain } & \multirow[t]{2}{*}{ Plasmid } & \multicolumn{4}{|c|}{ PEP-dependent phosphorylation of: } & \multicolumn{4}{|c|}{ ATP-dependent phosphorylation of: } \\
\hline & & Glc & Man & Nag & Fru & Glc & Man & Nag & Fru \\
\hline MD353 & - & $63 \pm 2$ & $74 \pm 3$ & $47 \pm 5$ & $86 \pm 15$ & $32 \pm 7$ & $17 \pm 4$ & $55 \pm 5$ & $3 \cdot 0 \pm 0 \cdot 2$ \\
\hline LPE6 & - & $1 \cdot 5 \pm 1$ & $2 \cdot 0 \pm 1$ & $2 \cdot 1 \pm 0 \cdot 8$ & $143 \pm 15$ & $32 \pm 3$ & $34 \pm 4$ & $51 \pm 13$ & $8 \cdot 0 \pm 1 \cdot 5$ \\
\hline LPE6 & pMJ18 & $44 \pm 3$ & $51 \pm 4$ & $51 \pm 4$ & $37 \pm 6$ & $49 \pm 5$ & $24 \pm 4$ & $49 \pm 6$ & $5 \cdot 0 \pm 2 \cdot 0$ \\
\hline LPE4 & - & $65 \pm 7$ & $68 \pm 7$ & $38 \pm 8$ & $75 \pm 10$ & $38 \pm 2$ & $20 \pm 4$ & $67 \pm 11$ & $7 \cdot 0 \pm 1 \cdot 4$ \\
\hline
\end{tabular}

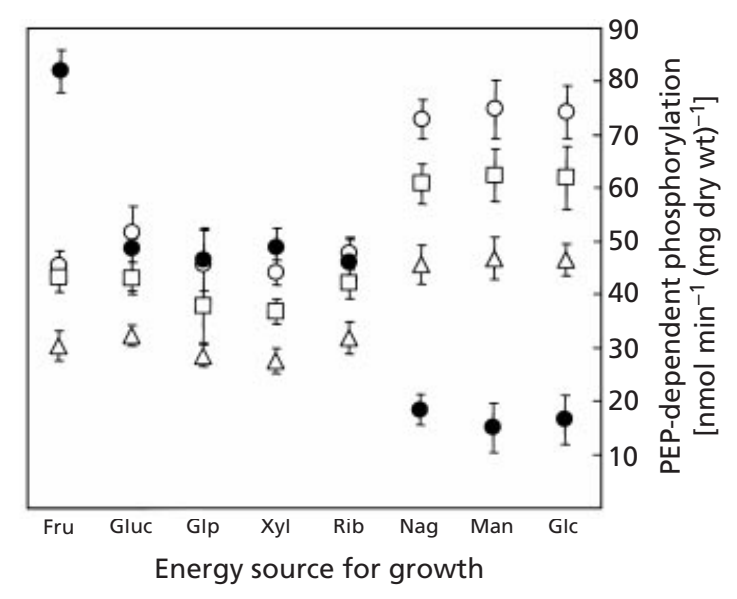

Fig. 1. Effect of the growth substrate on the rate of PEP-dependent phosphorylation in $L$. pentosus MD353 permeabilized cells. Substrates for phosphorylation: glucose $(\square)$, fructose $(\bullet)$, mannose $(\bigcirc)$, and $N$-acetylglucosamine $(\triangle)$. Values are the means \pm standard deviation (error bars) for three separate experiments. The reactions were carried out with $10 \mathrm{mM}$ PEP and $10 \mathrm{mM}{ }^{14} \mathrm{C}$-labelled sugar (specific activity 200 d.p.m. nmol ${ }^{-1}$ ) under conditions described in Methods. Cells were grown in MCD medium supplemented with $0.5 \%(\mathrm{w} / \mathrm{v})$ of the corresponding sugar, and harvested at the mid-exponential phase of growth $\left(\mathrm{OD}_{600} 0 \cdot 5\right)$. Fru, fructose; Gluc, gluconate; Glp, glycerol; Xyl, xylose; Rib, ribose; Nag, $\mathrm{N}$-acetylglucosamine; Man, mannose; Glc, glucose.

mutant LPE6 still showed wild-type levels of ATPdependent phosphorylation of glucose, mannose and $\mathrm{N}$ acetylglucosamine. These results indicated that the sugar-specific ATP-dependent kinase(s) activities were not affected by the mutation in EIIB ${ }^{\text {Man }}$. This last observation is compatible with the presence of (an)other non-phosphorylating uptake system(s) for these sugars in L. pentosus, which is/are responsible for the slow growth of mutant LPE6 on these compounds.
The rate of PEP-dependent phosphorylation of fructose was increased about $1 \cdot 7$-fold in LPE6 compared to that of MD353. Introduction of pMJ18 into LPE6 resulted in a 3.5 -fold decrease of the PEP-dependent phosphorylation rate of fructose compared to that of the untransformed mutant. These results correlated with the growth behaviour of LPE6 and LPE6/pMJ18 on fructose, as described in Table 1 . In contrast to LPE6, no significant difference was observed in the rates of PEPor ATP-dependent phosphorylation of the four sugars between LPE4 and wild-type bacteria. Finally, we found that neither PEP- nor ATP-dependent phosphorylation of sucrose could be detected in any of the strains tested (data not shown). Therefore, sucrose is presumably not a PTS sugar in L. pentosus. Furthermore, the lack of sucrose phosphorylation indicated that this sugar is metabolized by a pathway which could not be identified in our assay conditions.

\section{Effect of growth substrate on PTS activities in L. pentosus MD353}

Next we determined the effect of the growth conditions on the four PTS activities detected in L. pentosus. This experiment was carried out with wild-type bacteria as reference (Fig. 1). A similar pattern of activities was observed for glucose, mannose and $\mathrm{N}$-acetylglucosamine. In each case the activities were increased about 1.6-fold when MD353 cells were cultivated on these substrates, as compared to the activities in cells grown on other energy sources. PEP-dependent phosphorylation of fructose increased $1 \cdot 8$-fold in cells grown on fructose compared to that of cells grown on ribose, xylose, glycerol or gluconate. Fructose PTS activity was strongly decreased in cells grown on glucose, mannose and $\mathrm{N}$-acetylglucosamine. These results strongly suggested that fructose is taken up via a PTS different from that of glucose, mannose and $\mathrm{N}$ acetylglucosamine. Moreover, the data further indicated 
Table 3. $\beta$-Glucosidase and $\beta$-galactosidase activities on $p$-nitrophenyl $\beta$-D-glucopyranoside or $p$-nitrophenyl $\beta$-D-galactopyranoside measured in permeabilized cells of $L$. pentosus

Growth was performed in MCD medium at $37^{\circ} \mathrm{C}$ and measurements were carried out in permeabilized exponentially grown cells $\left(\mathrm{OD}_{600} \sim 0.5\right)$. All strains were pre-grown for $8 \mathrm{~h}$ in MCD medium containing $0.5 \%(\mathrm{w} / \mathrm{v})$ of glucose (Glc), mannose (Man) or fructose (Fru) according to the repressing energy source tested. For the induced and non-repressed condition (no add.), cells were pregrown overnight in $0.5 \%(\mathrm{w} / \mathrm{v})$ cellobiose or lactose. $\beta$-Glucosidase and $\beta$-galactosidase activities are expressed as nmol $p$-nitrophenol formed $\min ^{-1}(\mathrm{mg} \mathrm{dry} \mathrm{wt})^{-1}$. The mean values of at least five ( $\beta$-glucosidase) or three $(\beta$-galactosidase) experiments and their standard deviations are presented.

\begin{tabular}{|c|c|c|c|c|c|c|c|c|c|}
\hline \multirow[t]{2}{*}{ Strain } & \multirow[t]{2}{*}{ Plasmid } & \multicolumn{4}{|c|}{$\begin{array}{c}\beta \text {-Glucosidase activity in cells grown on } \\
0.5 \% \text { cellobiose }\end{array}$} & \multicolumn{4}{|c|}{$\begin{array}{c}\beta \text {-Galactosidase activity in cells grown on } \\
0.5 \% \text { lactose }\end{array}$} \\
\hline & & No add. & $0.5 \%$ Glc & $\begin{array}{l}0.5 \% \\
\text { Man }\end{array}$ & $0.5 \%$ Fru & No add. & $0.5 \%$ Glc & $\begin{array}{l}0.5 \% \\
\text { Man }\end{array}$ & $0.5 \%$ Fru \\
\hline MD353 & - & $61 \pm 11$ & $1 \cdot 1 \pm 0 \cdot 7$ & $1 \cdot 3 \pm 0.8$ & $2 \cdot 7 \pm 1 \cdot 1$ & $44 \pm 7$ & $0 \cdot 7 \pm 0 \cdot 2$ & $0.9 \pm 0.5$ & $2 \cdot 0 \pm 0 \cdot 7$ \\
\hline LPE6 & - & $58 \pm 9$ & $16 \cdot 6 \pm 4 \cdot 3$ & $14 \cdot 0 \pm 3 \cdot 0$ & $1 \cdot 0 \pm 0 \cdot 3$ & $38 \pm 6$ & $10 \cdot 6 \pm 3 \cdot 0$ & $8 \cdot 1 \pm 3 \cdot 9$ & $0 \cdot 6 \pm 0 \cdot 1$ \\
\hline LPE6 & pMJ18 & $63 \pm 12$ & $1 \cdot 5 \pm 0 \cdot 4$ & $2 \cdot 1 \pm 0 \cdot 5$ & $11 \cdot 4 \pm 2 \cdot 9$ & $39 \pm 4$ & $1 \cdot 1 \pm 0 \cdot 5$ & $1 \cdot 4 \pm 0 \cdot 4$ & $8 \cdot 6 \pm 2 \cdot 0$ \\
\hline LPE4 & - & $57 \pm 9$ & $40 \pm 10$ & $42 \pm 3$ & $51 \pm 16$ & $45 \pm 4$ & $18 \cdot 7 \pm 4 \cdot 2$ & $16 \cdot 0 \pm 5 \cdot 5$ & $15 \cdot 9 \pm 2 \cdot 5$ \\
\hline
\end{tabular}

Table 4. Rates of PEP-dependent phosphorylation of fructose measured in permeabilized cells of $L$. pentosus

Growth was performed in MCD medium at $37^{\circ} \mathrm{C}$ and measurements were carried out in permeabilized exponentially grown cells $\left(\mathrm{OD}_{600} \sim 0.5\right)$. All strains were pre-grown for $8 \mathrm{~h}$ in MCD medium containing $0.5 \%$ of glucose (Glc), mannose $(\mathrm{Man}), \mathrm{N}-$ acetylglucosamine ( $\mathrm{Nag}$ ) or glycerol (Glp). Under inducing conditions, $0.5 \%(\mathrm{w} / \mathrm{v}$ ) fructose (Fru) was added to the growth medium. Experiments were carried out as described in Table 2. Phosphorylation rates are expressed as nmol ${ }^{14} \mathrm{C}-$ labelled sugar phosphorylated $\min ^{-1}(\mathrm{mg} \text { dry } \mathrm{wt})^{-1}$. The mean values of two or three experiments and their standard deviations are presented.

\begin{tabular}{|c|c|c|c|c|c|c|c|c|c|}
\hline \multirow[t]{2}{*}{ Strain } & \multirow[t]{2}{*}{ Plasmid } & \multicolumn{4}{|c|}{ Growth condition (non-inducing) } & \multicolumn{4}{|c|}{ Growth condition (inducing) $:+0.5 \%$ Fru } \\
\hline & & $\begin{array}{c}0.5 \% \\
\text { Glp }\end{array}$ & $\begin{array}{c}0.5 \% \\
\text { Glc }\end{array}$ & $\begin{array}{l}0.5 \% \\
\text { Man }\end{array}$ & $\begin{array}{c}0.5 \% \\
\text { Nag }\end{array}$ & $\begin{array}{c}0.5 \% \\
\text { Glp }\end{array}$ & $\begin{array}{c}0.5 \% \\
\text { Glc }\end{array}$ & $\begin{array}{l}0.5 \% \\
\text { Man }\end{array}$ & $\begin{array}{c}0.5 \% \\
\text { Nag }\end{array}$ \\
\hline MD353 & - & $49 \pm 4$ & $16 \pm 1$ & $15 \pm 1$ & $18 \pm 3 \cdot 4$ & $85 \pm 10$ & $28 \pm 4$ & $24 \pm 2$ & $31 \pm 3$ \\
\hline LPE6 & - & $38 \pm 4$ & $43 \pm 3$ & $41 \pm 1$ & $38 \pm 4$ & $143 \pm 11$ & $149 \pm 10$ & $138 \pm 8$ & $128 \pm 11$ \\
\hline LPE6 & pMJ18 & $12 \pm 1$ & $12 \pm 0 \cdot 5$ & $13 \pm 0 \cdot 5$ & $13 \pm 3$ & $37 \pm 3$ & $18 \pm 1$ & $14 \pm 1 \cdot 5$ & $21 \pm 1$ \\
\hline LPE4 & - & $51 \pm 5$ & $17 \pm 1$ & $14 \pm 3$ & $22 \pm 2$ & $73 \pm 12$ & $25 \pm 3$ & $23 \pm 3$ & $35 \pm 5$ \\
\hline
\end{tabular}

that these three sugars exert a repressive effect on fructose PTS activity.

\section{Effect of EllB ${ }^{\text {Man }}$ and $\operatorname{ccpA}$ mutations on CR of $\beta$-glucosidase and $\beta$-galactosidase activities in L. pentosus}

Our original interest was to study the control of carbon utilization in L. pentosus. This prompted us to investigate whether the regulation of some catabolic pathways by readily fermentable sugars (e.g. the four PTS sugars identified above) was affected in the $2 \mathrm{DG}^{\mathrm{R}}$ mutant LPE6 and/or in the $\triangle c c p A$ mutant LPE4. For this study, we sought catabolic enzymes whose activity was subject to glucose-mediated CR. It is known from studies in other bacteria that the synthesis of two enzymes, $\beta$-glucosidase and $\beta$-galactosidase, is subject to glucose-mediated CR. Screening of L. pentosus revealed that the activity of these two enzymes could be detected in this species and was induced by the presence of cellobiose and lactose, respectively, in the growth medium. Moreover, activity of both enzymes was subject to strong glucose-mediated repression in $L$. pentosus. The influence of glucose, mannose and fructose on the activity of the two enzymes was determined (Table 3). The three hexoses showed a repressive effect on the expression of the two catabolic enzymes in the wild-type strain; the repressive effect mediated by fructose was less pronounced than that mediated by glucose or mannose. In the $\Delta c c p A$ mutant, the repression which glucose, mannose and fructose exerted on the $\beta$ glucosidase activity was almost totally relieved $(\leqslant 1 \cdot 4-$ fold repression in LPE4 compared with 22- to 55-fold repression in MD353). Repression exerted on $\beta$ galactosidase activity was also relieved although some level of repression remained $(\leqslant 2 \cdot 8$-fold repression in LPE4 compared with 22- to 63-fold repression in MD353). These results indicated that the synthesis of both enzymes was subject to a strong CcpA-dependent CR in L. pentosus. The synthesis of both enzymes in 

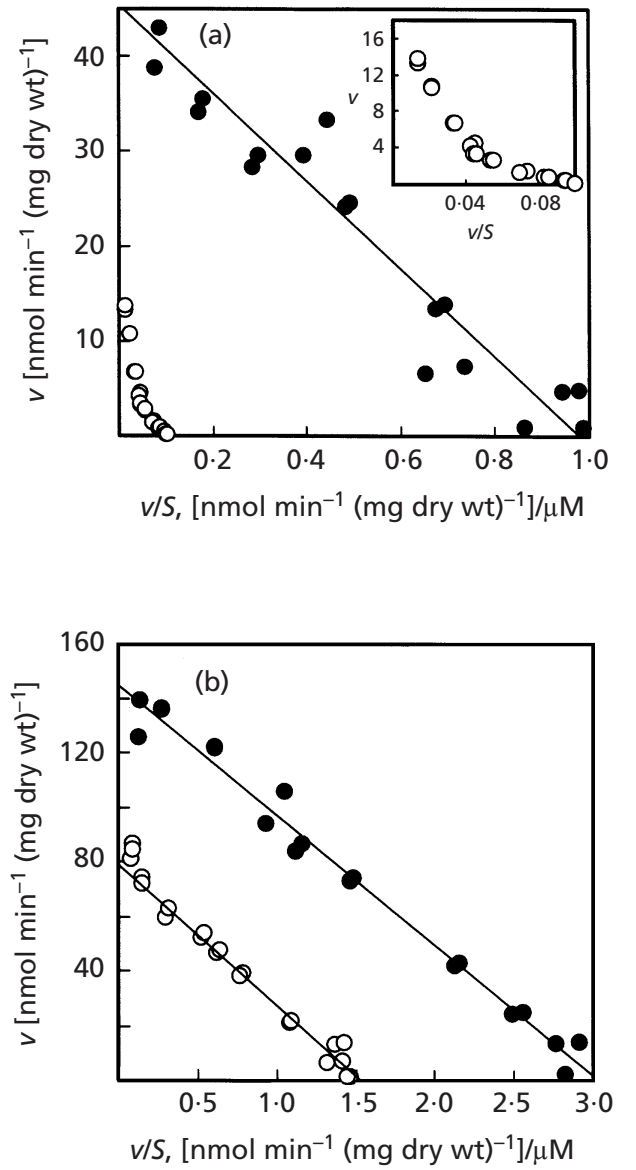

Fig. 2. Eadie-Hofstee plot of initial rate of $D-\left[U-{ }^{14} \mathrm{C}\right]$ fructose uptake in starved cells of LPE6 (O) and MD353 (O) grown in either glucose (a) or fructose (b). The data obtained with cells of MD353 grown in glucose are enlarged in the inset of (a) (units of $v$ and $S$ as on main axes). Initial rates of uptake, $v$, were determined by taking a sample at $15 \mathrm{~s}$ after the start of the transport experiments as described in Methods. The sugar concentration, $S$, ranged from $1 \mu \mathrm{M}$ to $1 \mathrm{mM}$. The inial rate of uptake is expressed in $\mathrm{nmol} \mathrm{min}^{-1}$ (mg dry wt) ${ }^{-1}$ and the substrate concentration in $\mu \mathrm{M}$.

LPE6 was partially relieved from CR mediated by glucose and mannose ( $\leqslant 4 \cdot 7$-fold repression in LPE6 compared with 55- to 63-fold repression in MD353), but an increased fructose-mediated CR could be detected in this strain (58- to 63-fold repression in LPE6 compared with 22-fold repression in MD353). In contrast, LPE6/ pMJ18 had lost most of the strong fructose-mediated CR observed in the untransformed mutant. These results indicate that in addition to CcpA, the EII ${ }^{\text {Man }}$ complex is a component of the glucose/mannose-mediated CR of $\beta$ glucosidase and $\beta$-galactosidase activities in L. pentosus, but not of the fructose-mediated CR.

\section{Regulation of fructose PTS activity in L. pentosus}

In the experiments described above, we noticed two interesting phenomena about fructose utilization: (i) fructose PTS activity was strongly decreased when MD353 cells were cultivated in the presence of EII ${ }^{\text {Man }}$ substrates (Fig. 1) ; (ii) mutant LPE6 showed an increased rate of growth on fructose, an increased rate of PEPdependent phosphorylation of fructose and an increased repression of $\beta$-glucosidase and $\beta$-galactosidase synthesis in the presence of fructose, compared to wild-type bacteria, while these effects were largely counteracted in the transformant pLPE6/pMJ18. To ascertain the role of the EII ${ }^{\text {Man }}$ complex and/or of CcpA in these phenomena, we tested the rates of PEP-dependent phosphorylation of fructose in the various strains grown in the presence of glucose, mannose, $\mathrm{N}$-acetylglucosamine and glycerol (the later is a neutral energy source in L. pentosus). From results shown in Fig. 1, it also appeared that fructose stimulated induction of fructose PTS activity. Therefore, we carried out similar experiments as described above with fructose as energy source (Table 4). Under both inducing and non-inducing conditions, the presence of glucose, mannose, and $\mathrm{N}$ acetylglucosamine in the growth medium caused a strong decrease of the rate of PEP-dependent phosphorylation of fructose in cells of MD353 compared to that determined in cells of the same strain grown on a non-PTS energy source, glycerol. This repressive effect was absent in mutant LPE6, but was still present in the $\triangle c c p A$ mutant, LPE4.

The data in Table 4 show two additional interesting results. Comparison of the rates of PEP-dependent phosphorylation of fructose measured in MD353 and LPE6 cells grown on glycerol plus fructose or glycerol alone showed a 3.5-fold induction of fructose PTS

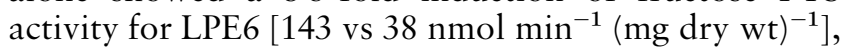
while this induction level was only $1 \cdot 7$-fold in MD353 [85 vs $49 \mathrm{nmol} \mathrm{min}^{-1}$ (mg dry wt) ${ }^{-1}$ ]. This result suggested that the fructose-mediated induction of fructose PTS activity is enhanced when the EII ${ }^{\mathrm{Man}}$ complex is inactive. Secondly, complementation of the EII Man activity in LPE6/pMJ18 partially restored the repressive effect of glucose, mannose and $\mathrm{N}$-acetylglucosamine on fructose PTS activity. Interestingly, the rates of PEPdependent phosphorylation of fructose in LPE6/pMJ18 grown in the presence of glycerol under either inducing or non-inducing conditions were lower than those in wild-type bacteria.

\section{Kinetics of fructose uptake in starved cells of MD353 and LPE6}

Previous reports have shown that fructose can be a substrate for PTS transporters of the mannose class in various micro-organisms (Bourassa et al., 1990; Erni et al., 1987; Martin-Verstraete et al., 1990; Wehmeier et al., 1995). If fructose could also be a substrate of EII ${ }^{\text {Man }}$ in L. pentosus, possibly its transport and phosphorylation via EII ${ }^{\mathrm{Man}}$ could lead to a different level of fructose PTS activity in cells of MD353 grown on fructose compared to that in LPE6. In order to determine whether fructose is a substrate of EII ${ }^{\text {Man }}$, we measured the kinetics of fructose uptake in cells of MD353 and LPE6 grown on either glucose or fructose. An Eadie-Hofstee plot of fructose uptake in glucose-grown cells of MD353 (Fig. 2a) revealed the presence of two transport systems 
for fructose: a high-affinity transport system [apparent $K_{\mathrm{m}} 52 \pm 1 \mu \mathrm{M}$ and $V_{\max } 4 \cdot 2 \pm 0.3 \mathrm{nmol} \mathrm{min}{ }^{-1}$ (mg dry $\mathrm{wt})^{-1}$ ] and a low-affinity transport system [apparent $K_{\mathrm{m}} 300 \pm 18 \mu \mathrm{M}$ and $V_{\max } 12 \cdot 9 \pm 0 \cdot 3 \mathrm{nmol} \mathrm{min}{ }^{-1}(\mathrm{mg}$ dry wt $)^{-1}$. In contrast, the kinetics of fructose uptake in glucose-grown cells of LPE6 (Fig. 2a) revealed the presence of a single high-affinity transport system [apparent $K_{\mathrm{m}} 46 \pm 5 \mu \mathrm{M}$ and $V_{\max } 47 \pm 3 \mathrm{nmol} \mathrm{min}^{-1}$ $\left.(\mathrm{mg} \text { dry wt })^{-1}\right]$. Since we could characterize the mutation of LPE6 as being presumably located in the EIIB $^{\text {Man }}$ domain, these results imply that the low-affinity uptake system for fructose of L. pentosus corresponds to EII ${ }^{\mathrm{Man}}$. An Eadie-Hofstee plot of fructose uptake in fructose-grown cells of MD353 and LPE6 (Fig. 2b) revealed the presence of the high-affinity system in both strains [apparent $K_{\mathrm{m}} \quad 52 \cdot 5 \pm 4 \mu \mathrm{M}$ and $V_{\max }$ $81 \pm 9 \mathrm{nmol} \mathrm{min}^{-1}(\mathrm{mg} \text { dry wt })^{-1}$, and apparent $K_{\mathrm{m}}$ $52 \cdot 1 \pm 5 \mu \mathrm{M}$ and $V_{\max } 155 \pm 11 \mathrm{nmol} \mathrm{min}{ }^{-1} \quad(\mathrm{mg}$ dry wt $)^{-1}$ for MD353 and LPE6, respectively]. However, the low rate of fructose uptake via the low-affinity transport system cannot be measured separately in the presence of the high-affinity system in fructose-grown cells of MD353 under our assay conditions. Finally, a comparison of the kinetics of fructose uptake in glucosegrown (Fig. 2a) and fructose-grown (Fig. 2b) cells of LPE6 showed a 3-2-fold induction of the high-affinity system by fructose.

\section{DISCUSSION}

Since the EII ${ }^{\mathrm{Man}}$ complex plays a major, although poorly characterized, role in glucose transport and phosphorylation in lactic acid bacteria, we have carried out a study to determine the role of the EII ${ }^{\mathrm{Man}}$ complex in transport and regulation of sugar utilization in L. pentosus. We used a $2 \mathrm{DG}^{\mathrm{R}}$ mutant of $L$. pentosus, LPE6 and a derivative of LPE6 in which the EII ${ }^{\text {Man }}$ mutation was complemented by a plasmid-encoded $\operatorname{man} B$ gene, to show that the EII Man complex of L. pentosus can transport and phosphorylate mannose, glucose, $\mathrm{N}$ acetylglucosamine and 2DG. This finding is in accordance with the typical broad substrate specificity of the mannose PTS transporter in bacteria (Postma et al., 1993).

Data presented in Fig. 1 showed that the rate of phosphorylation of fructose in wild-type bacteria was increased in fructose medium compared to non-PTS sugars and was strongly repressed in the presence of EII $^{\text {Man }}$ substrates. In LPE6, phosphorylation of fructose was higher while that of EII ${ }^{\mathrm{Man}}$ substrates was greatly decreased compared to wild-type bacteria. Finally, expression in LPE6 of manB on a multi-copy plasmid largely restored the capacity to phosphorylate EII ${ }^{\mathrm{Man}}$ substrates but strongly suppressed phosphorylation of fructose (Table 2). To further our understanding of these phenomena, we studied fructose PTS activity and fructose uptake in the different strains. Fructose-uptake studies in wild-type bacteria revealed the presence of two transport systems for fructose, a high-affinity transport system and a low-affinity transport system. By comparing fructose uptake rates in wild-type bacteria with those in LPE6, EII ${ }^{\mathrm{Man}}$ was shown to be responsible for the low-affinity system, while the high-affinity system constitutes a different transport system, which we will refer to as $\mathrm{EII}^{\mathrm{Fru}}$.

Our data clearly demonstrate that EII ${ }^{\mathrm{Fru}}$ activity in $L$. pentosus is dependent on two factors: one involving a $3 \cdot 2$-fold induction by growth on fructose, and another one involving a negative regulation mediated by the presence of glucose/mannose/N-acetylglucosamine in the growth medium. Mutant LPE6 appeared to lack the negative regulation of EII ${ }^{\mathrm{Fru}}$ activity. The mechanism of this negative regulation is not known but the data presented in Fig. 1 suggest that the phosphorylation state of the EII ${ }^{\text {Man }}$ complex might be an important factor. In the presence of gluconate, glycerol, xylose or ribose, EII ${ }^{\mathrm{Fru}}$ activity was elevated in comparison with that in the presence of sugars that are substrates of EII ${ }^{\text {Man }}$. It should be noted that PEP-dependent phosphorylation of glucose, mannose and $\mathrm{N}$-acetylglucosamine could be detected in glycerol- or ribose/ xylose/gluconate-grown cells, indicating that the EII ${ }^{\text {Man }}$ complex is active under these growth conditions. Since no transport and phosphorylation via EII ${ }^{\mathrm{Man}}$ occurs under these conditions, most likely the EII ${ }^{\text {Man }}$ complex is phosphorylated, while it is unphosphorylated in the presence of the substrates of EII ${ }^{\text {Man }}$.

In this study we have also investigated the role of the global regulator CcpA on sugar transport and phosphorylation, and compared the effects of CcpA and the EII ${ }^{\mathrm{Man}}$ complex on EII ${ }^{\mathrm{Fru}}$ activity and on CR of two metabolic enzyme activities. EII ${ }^{\mathrm{Man}}$ and EII ${ }^{\mathrm{Fru}}$ activities were similar in a $\triangle c c p A$ mutant (LPE4) and in wild-type bacteria. These results indicate that the $c c p A$ mutation has no effect on EII ${ }^{\mathrm{Man}}$ and EII ${ }^{\mathrm{Fru}}$ activity in L. pentosus. They also indicate that the growth impairment of mutant LPE4 on various sugars did not result from inefficient transport and phosphorylation of these compounds. It has recently been shown that $B$. subtilis $c c p A$ mutants grow poorly in minimal media due to an inefficient utilization of glutamate as the source of nitrogen (Faires et al., 1999). The results presented here might indicate that the growth deficiency of LPE4 is caused by decreased nitrogen assimilation, as shown for the B. subtilis ccpA mutants.

Our results showed that expression of $\beta$-glucosidase and $\beta$-galactosidase is down-regulated by a CcpA-dependent mechanism in the presence of glucose, mannose and fructose. The repression mediated by glucose and mannose (EII ${ }^{\text {Man }}$ substrates) on these enzymes was partially relieved in LPE6 whereas the fructose-mediated repression was increased. Moreover, fructose-mediated repression of the two enzymes was also partially relieved in LPE6/pMJ18, a strain that showed low fructose PTS activity and inefficient growth on fructose. The evidence presented here suggests that fructose-mediated repression of $\beta$-glucosidase and $\beta$-galactosidase expression in L. pentosus is dependent on $\mathrm{EII}^{\mathrm{Fru}}$ activity, whereas the glucose/mannose-mediated repression is 
dependent on EII ${ }^{\text {Man }}$ activity. Thus, repression of $\beta$ glucosidase and $\beta$-galactosidase expression may result from inefficient metabolism of a particular compound due to a lower transport and phosphorylation activity. As referred to in the Introduction, the paradigm of $\mathrm{HPr}(\mathrm{Ser}-\mathrm{P}) / \mathrm{CcpA}$-dependent CR in B. subtilis describes that this regulatory pathway is activated by accumulation of phosphorylated glycolytic intermediates (Galinier et al., 1998; Stülke \& Hillen, 1999), and dephosphorylation of HPr on the His-15 residue (this form of HPr does not interact with CcpA; Deutscher et al., 1995), two conditions which are met during sugar transport via the PTS. Thus, considering the predominant role of $\mathrm{EII}^{\mathrm{Man}}$ and $\mathrm{EII}^{\mathrm{Fru}}$ in transport and phosphorylation of glucose/mannose and fructose, we conclude that these two PTSs play a major role, but an indirect one, in the CcpA-mediated CR of $\beta$-glucosidase and $\beta$-galactosidase expression in L. pentosus.

To summarize, we conclude that (i) regulation of EII ${ }^{\text {Fru }}$ synthesis by EII ${ }^{\text {Man }}$ sugars in L. pentosus is CcpAindependent, and (ii) the negative regulation of EII ${ }^{\mathrm{Fru}}$ activity is associated with a functional and active EII ${ }^{\mathrm{Man}}$ complex. The negative effect exerted by EII ${ }^{\mathrm{Man}}$ is more pronounced when manB encoding the EIIB ${ }^{\mathrm{Man}}$ subunit is expressed from a multi-copy plasmid. A similar phenomenon has been previously observed for several $S$. salivarius mutants deficient in EII ${ }^{\text {Man }}$ activity (Bourassa \& Vadeboncoeur, 1992). In these mutants, which lacked a cytoplasmic component of EII ${ }^{\text {Man }}$ called EIIAB $\mathrm{L}$ Man (Bourassa et al., 1990; Vadeboncoeur \& Gauthier, 1987), expression of an inducible fructose PTS was derepressed in glucose- and fructose-grown cells. Although the role of CcpA in regulating the fructose PTS was not investigated in this species, its induction in the absence of EIIAB $\mathrm{L}$ Man suggests that the synthesis of $\mathrm{EII}^{\mathrm{Fru}}$ in S. salivarius and L. pentosus might be regulated via a similar mechanism. In both species, the nature of the regulatory component is still an open question. Nevertheless, our results presented in Fig. 1 and Table 4 suggest a critical role of the phosphorylation state of the EIIB $^{\text {Man }}$ subunit in the regulation of EII ${ }^{\mathrm{Fru}}$ activity in L. pentosus. However, another PTS component, $\mathrm{HPr}$, might also be responsible for the $\mathrm{EII}^{\mathrm{Fru}}$ activities described in this work. For instance, differences in the relative levels of phosphorylation of HPr at His-15 and Ser-46, resulting from the mutation in EIIB ${ }^{\text {Man }}$ and from overexpression of $\operatorname{man} B$, due to the presence of multiple copies of pMJ18, could possibly modify the regulatory function of HPr. Indeed, expression of several bacterial genes encoding substrate-specific PTSs has been shown to be regulated by a mechanism involving phosphorylation of an antiterminator protein by $\mathrm{HPr}-15$ or by one of the EII components belonging to the specific PTS (for a review see Stülke \& Hillen, 1998). A molecular genetic analysis of the L. pentosus $\mathrm{EII}^{\mathrm{Man}}$ - and EII ${ }^{\mathrm{Fru}}$-encoding genes, as well as of the ptsHI operon, is needed to unravel this regulatory mechanism in more detail.

In this report we have provided evidence that the EII ${ }^{\text {Man }}$ complex is an important component of CR in $L$. pentosus. First of all, as a major actor in the catabolism of glucose, mannose and $\mathrm{N}$-acetylglucosamine, the EII $^{\text {Man }}$ complex provides a strong signal to the global CcpA-dependent CR pathway. Similarly, the EII ${ }^{\text {Fru }}$ complex is an important component of the fructosemediated CcpA-dependent CR. In addition, the EII ${ }^{\text {Man }}$ complex is specifically involved in inhibition of the EII $^{\mathrm{Fru}}$ activity. Our data strongly suggest a critical role of the phosphorylation state of the $\mathrm{EIIB}^{\mathrm{Man}}$ subunit in this regulatory control. Further experiments designed to test the role of this subunit should yield a better insight into the global mechanisms of CR in lactobacilli.

\section{ACKNOWLEDGEMENTS}

We would like to acknowledge Gaspar Pérez-Martínez (Instituto de Agroquímica y Technología de Alimentos, Valencia, Spain) for kindly providing us with plasmid pMJ18, Monique Zagorec (Institut National de la Recherche Agronomique, Jouy-en-Josas, France) for suggestions concerning the use of MCD medium, Christien Lokman (TNO Voeding, The Netherlands) for the gift of strain LPE6 and Yvonne Borsboom for technical assistance. This work was supported by a grant from the EU (BIO2-CT92-0137).

\section{REFERENCES}

Abe, K. \& Uchiba, K. (1989). Correlation between depression of catabolite control of xylose metabolism and a defect in the phosphoenolpyruvate:mannose phosphotranferase system in Pediococcus halophilus. J Bacteriol 171, 1793-1800.

Bourassa, S. \& Vadeboncoeur, C. (1992). Expression of an inducible enzyme II fructose and activation of a cryptic enzyme II glucose in glucose-grown cells of spontaneous mutants of Streptococcus salivarius lacking the low-molecular-mass of III ${ }^{\text {man }}$, a component of the phosphoenolpyruvate:mannose phosphotransferase system. J Gen Microbiol 138, 769-777.

Bourassa, S., Gauthier, L., Giguère, R. \& Vadeboncoeur, C. (1990). A III ${ }^{\mathrm{Man}}$ protein is involved in the transport of glucose, mannose and fructose by oral streptococci. Oral Microbiol Immunol 5, 288-297.

Chaillou, S., Lokman, B. C., Leer, R. J., Posthuma, C., Postma, P. W. \& Pouwels, P. H. (1998). Cloning, sequence analysis and characterization of the genes involved in isoprimeverose metabolism in Lactobacillus pentosus. J Bacteriol 180, 2312-2320.

Chaillou, S., Pouwels, P. H. \& Postma, P. W. (1999). Transport of $\mathrm{D}$-xylose in Lactobacillus pentosus, Lactobacillus casei and Lactobacillus plantarum: evidence for a mechanism of facilitated diffusion via the phosphoenolpyruvate:mannose phosphotransferase system. J Bacteriol 181, 4768-4773.

Chen, Y. Y., Hall, T. H. \& Burne, R. A. (1998). Streptococcus salivarius urease expression: involvement of the phosphoenolpyruvate: sugar phosphotransferase system. FEMS Microbiol Lett $165,117-122$

Deutscher, J. \& Saier, M. H., Jr (1983). ATP-dependent, protein kinase-catalysed phosphorylation of a seryl residue in $\mathrm{HPr}$, the phosphoryl carrier protein of the phosphotransferase system in Streptococcus pyogenes. Proc Natl Acad Sci U S A 80, 6790-6794.

Deutscher, J., Küster, E., Bergstedt, U., Charrier, v. \& Hillen, w. (1995). Protein kinase-dependent $\mathrm{HPr} / \mathrm{CcpA}$ interaction links glycolytic activity to carbon catabolite repression in Grampositive bacteria. Mol Microbiol 15, 1049-1053.

Erni, B., Zanolari, B. \& Kocher, H. P. (1987). The mannose permease of Escherichia coli consists of three different proteins. 
Amino acid sequence and function in sugar transport, sugar phosphorylation, and penetration of phage lambda DNA. J Biol Chem 262, 5238-5247.

Faires, N., Tobisch, S., Bachem, S., Martin-Verstraete, I., Hecker, M. \& Stülke, J. (1999). The catabolite control protein CcpA controls ammonium assimilation in Bacillus subtilis. $J \mathrm{Mol}$ Microbiol Biotechnol 1, 141-148.

Fujita, Y., Miwa, Y., Galinier, A. \& Deutscher, J. (1995). Specific recognition of the Bacillus subtilis gnt cis-acting cataboliteresponsive element by a protein complex formed between CcpA and seryl-phosphorylated HPr. Mol Microbiol 17, 953-960.

Galinier, A., Kravanja, M., Engelmann, R., Hengsterberg, W., Kilhoffer, M.-C., Deutscher, J. \& Haiech, J. (1998). New protein kinase and protein phosphatase families mediate signal transduction in bacterial catabolite repression. Proc Natl Acad Sci U S A 95, 1823-1828.

Gauthier, L., Bourassa, S., Brochu, D. \& Vadeboncoeur, C. (1990). Control of sugar utilization in oral streptococci. Properties of phenotypically distinct 2-deoxyglucose-resistant mutants of Streptococcus salivarius. Oral Microbiol Immunol 5, 352-359.

Gonzy-Tréboul, G., de Waard, J. H., Zagorec, M. \& Postma, P. W. (1991). The glucose permease of the phosphotransferase system of Bacillus subtilis: evidence for $\mathrm{II}^{\mathrm{Glc}}$ and $\mathrm{III}^{\mathrm{Glc}}$ domains. Mol Microbiol 5, 1241-1249.

Gosalbes, M. J., Monedero, V., Alpert, C. A. \& Pérez-Martínez, G. (1997). Establishing a model to study the regulation of the lactose operon in Lactobacillus casei. FEMS Microbiol Lett 148, 83-89.

Jones, B. E., Dossonet, V., Küster, E., Hillen, W., Deutscher, J. \& Klevit, R. E. (1997). Binding of the catabolite repressor protein CcpA to its DNA target is regulated by phosphorylation of its corepressor HPr. J Biol Chem 272, 26530-26535.

Lapointe, R., Frenette, M. \& Vadeboncoeur, C. (1993). Altered expression of several genes in $\mathrm{III}_{\mathrm{L}}^{\mathrm{man}}$-defective mutants of Streptococcus salivarius demonstrated by two-dimensional gel electrophoresis of cytoplasmic proteins. Res Microbiol 144, 305-316.

Lauret, R., Morel-Deville, F., Berthier, F., Champonier-Verges, M., Postma, P. W., Ehrlich, S. D. \& Zagorec, M. (1996). Carbohydrate utilization in Lactobacillus sake. Appl Environ Microbiol 62, 1922-1927.

Ledesma, O. V., De Ruiz, A. P., Oliver, G., De Siori, G. S., Raibaud, P. \& Galpin, J. V. (1977). A synthetic medium for comparative nutritional studies of lactobacilli. J Appl Bacteriol 42, 123-133.

Lokman, B. C., van Santen, P., Verdoes, J. C., Krüse, J., Leer, R. J., Posno, M. \& Pouwels, P. H. (1991). Organization and characterization of the three genes involved in D-xylose catabolism in Lactobacillus pentosus. Mol Gen Genet 230, 161-169.

Lokman, B. C., Heerikhuisen, M., Leer, R. J., van den Broek, A., Borsboom, Y., Chaillou, S., Postma, P. \& Pouwels, P. H. (1997). Regulation of expression of the Lactobacillus pentosus $x y l A B-$ operon. J Bacteriol 179, 5391-5397.

Lortie, L.-A., Pelletier, M., Vadeboncoeur, C. \& Frenette, M.
(2000). The gene encoding $\operatorname{IIAB}_{\mathrm{L}}^{\mathrm{Man}}$ in Streptococcus salivarius is part of a tetracistronic operon encoding a phosphoenolpyruvate: mannose/glucose phosphotransferase system. Microbiology 146, 677-685.

Martin-Verstraete, I., Débarbouillé, M., Klier, A. \& Rapoport, G. (1990). Levanase operon of Bacillus subtilis includes a fructosespecific phosphotransferase system regulating the expression of the operon. J Mol Biol 214, 657-671.

Postma, P. (1977). Galactose transport in Salmonella typhimurium. J Bacteriol 129, 630-639.

Postma, P. W., Lengeler, J. W. \& Jacobson, G. R. (1993). Phosphoenolpyruvate: carbohydrate phosphotransferase systems of bacteria. Microbiol Rev 57, 543-594.

Reizer, J., Novotny, M. J., Hengstenberg, W. \& Saier, M. H., Jr (1984). Properties of ATP-dependent protein kinase from Streptococcus pyogenes that phosphorylates a seryl-residue in $\mathrm{HPr}$, a phosphocarrier protein of the phosphotransferase system. J Bacteriol 160, 333-340.

Reizer, J., Hoischen, C., Titgemeyer, F., Rivolta, C., Rabus, R., Stülke, J., Karamat, D., Saier, M. H., Jr \& Hillen, W. (1998). A novel protein kinase that controls carbon catabolite repression in bacteria. Mol Microbiol 27, 1157-1169.

Stülke, J. \& Hillen, W. (1999). Carbon catabolite repression in bacteria. Curr Opin Microbiol 2, 195-201.

Thompson, J. \& Chassy, B. M. (1985). Intracellular phosphorylation of glucose analogs via the phosphoenolpyruvate: mannose phosphotransferase system in Streptococcus lactis. J Bacteriol 162, 224-234.

Vadeboncoeur, C. \& Gauthier, L. (1987). The phosphoenolpyruvate: sugar phosphotransferase system of Streptococcus salivarius: identification of $\mathrm{III}^{\mathrm{Man}}$ protein. Can J Microbiol 33, 118-122.

Vadeboncoeur, C. \& Pelletier, M. (1997). The phosphoenolpyruvate phosphotransferase system of oral streptococci and its role in the control of sugar metabolism. FEMS Microbiol Rev 19, 187-207.

Veyrat, A., Monedero, V. \& Pérez-Martinez, G. (1994). Glucose transport by the phosphoenolpyruvate:mannose phosphotransferase system in Lactobacillus casei ATCC 393 and its role in carbon catabolite repression. Microbiology 140, 1141-1149.

Veyrat, A., Gosalbes, M. J. \& Pérez-Martinez, G. (1996). Lactobacillus curvatus has a glucose transport system homologous to the mannose family of phosphoenolpyruvate-dependent phosphotransferase systems. Microbiology 142, 3469-3477.

Wehmeier, U. F., Wöhrl, B. M. \& Lengeler, J. W. (1995). Molecular analysis of the phosphoenolpyruvate-dependent L-sorbose phosphotransferase system for Klebsiella pneumoniae and of its multidomain structure. Mol Gen Genet 246, 610-618.

Received 30 August 2000; revised 21 December 2000; accepted 22 December 2000 